\title{
O retrato linguístico de uma professora entre-línguas
}

El retrato lingüístico de una profesora entre-lenguas

Linguistic Portrait of a Bilingual Teacher

\section{Antonieta Heyden-Megale* (iD orcid.org/0000-0003-2742-455}

\author{
Artículo de investigación \\ Revista Colombiana de Educación, N.7 75. Segundo semestre de 2018, Bogotá, Colombia \\ doi: 10.17227/rce.num75-8112 \\ Para citar este artículo: Heyden, A. (2018). O retrato linguístico de uma professora entre-línguas. \\ Revista Colombiana de Educación, 75, 287-309. \\ (ब) $(1)$




\title{
Resumo
}

Este estudo teve como objetivo entender os posicionamentos de uma professora de uma escola bilíngue em relação ao seu repertório linguístico. Para tanto, a participante da pes quisa foi convidada a desenhar seu retrato linguístico e, após sua elaboração, narrá-lo a fim de explicitar a alocação das línguas em seu corpo. O exame das narrativas produzidas por Carla revelou que ela se posicionou em relação a seu repertório linguístico a partir de uma visão monoglóssica de língua, na qual suas línguas funcionariam independentemente uma da outra.

\section{Palavras-chave}

bilíngue; repertório linguístico; retrato linguístico; narrativa

\section{Palabras clave}

bilingüe; repertorio lingüístico; retrato lingüístico; narrativa

\section{Resumen}

Este estudio tuvo como objetivo entender las posturas de una profesora de un colegio bilingüe frente a su repertorio lingüístico. Para esto, la participante de la investigación fue invitada a elaborar su retrato lingüístico y, después de ello, narrarlo con el fin de explicitar la localización de las lenguas en su cuerpo. El examen de las narrativas producidas por Carla reveló que se posicionó en relación a su repertorio lingüístico a partir de una visión monoglósica de lengua, en la cual sus lenguas funcionarían independientemente una de la otra.

\begin{abstract}
This study aimed at understanding the positioning of a teacher of a bilingual school in relation to her linguistic repertoire. To this end, the research participant was invited to draw her linguistic portrait and, after its elaboration, to narrate it in order to make explicit the allocation of the languages in her body. An examination of the narratives produced by Carla revealed that she positioned herself in relation to her linguistic repertoire from a monoglassic view of language, in which her languages would function independently of one another.
\end{abstract}

\section{Keywords}

bilingual; linguistic repertoire; linguistic portrait; narrative 


\section{Introdução}

O modelo educativo geralmente referido por Educação Bilíngue de Prestígio ou de Elite é assim denominado devido às condições financeiras favoráveis dos alunos que podem frequentar as escolas que o seguem. Nelas, a instrução ocorre, concomitantemente, em português e em uma língua de prestígio internacional.

Anualmente, diversas escolas bilíngues desse tipo são abertas nas grandes capitais e diversas escolas regulares monolíngues passaram a adotar currículos bilíngues a fim de serem nomeadas escolas bilíngues e, com isso, atingirem uma maior parcela da população brasileira de alta renda.

Ao refletir sobre a gênese e natureza desse tipo de escola, Marcelino (2009) esclarece que, tradicionalmente, os pais brasileiros escolhiam os colégios para seus filhos com base na proposta geral de ensino da instituição. A aprendizagem de uma língua estrangeira era "delegada" aos institutos de idiomas, ainda que os currículos das escolas nas quais seus filhos estavam matriculados contemplasse o ensino de uma língua adicional. Com o tempo, as escolas regulares passaram a terceirizar o ensino de idiomas estrangeiros a fim de melhorar o ensino dessas línguas que era considerado ineficiente por várias razões, como falta de fluência dos professores, número de aulas insuficiente e muitos alunos em sala de aula. Porém, a terceirização também mostrou-se ineficiente, uma vez que pressupõe a entrada de uma instituição - os institutos de idiomas -, com seus próprios princípios e diretrizes, dentro de uma escola regular que funciona e entende os processos de ensino-aprendizagem de modos, muitas vezes, distintos dos observados por esses institutos. É nesse momento, então, que surgem as Escolas Bilíngues Brasileiras. Essas escolas tiveram grande adesão das famílias brasileiras, que passaram a percebê-las como uma oportunidade cômoda para "conseguir duas funções tão importantes e necessárias na educação de seus filhos: uma educação de qualidade e o ensino de um idioma" (Marcelino, 2009, p. 2).

Apesar do crescimento significativo das escolas de educação bilíngue de elite, não há nenhuma lei nacional que embase esse tipo de educação. Essa falta de regulamentação por parte do MEc faz com que, segundo Mello (2010), a própria definição do que seja uma escola bilíngue de elite se tornasse um tema bastante controverso e repleto de mal-entendidos. Essa autora salienta que a expressão "educação bilíngue" é utilizada de maneira abrangente para caracterizar diferentes formas de ensino nas quais os alunos recebem instrução, ou parte dela, em uma língua diferente da que utilizam em casa. Segundo a especialista, os modelos e tipos de educação 
bilíngue são variados e diferem quanto aos objetivos, às características dos alunos participantes, à distribuição do tempo de instrução nas línguas envolvidas, às abordagens e práticas pedagógicas, entre outros aspectos do uso das línguas e do contexto em questão.

A demanda por parâmetros legais que regulem e norteiem as escolas de Educação Bilíngue de Prestígio torna-se cada vez mais premente em face do aumento do número dessas escolas e, por conseguinte, da necessidade de formação específica de professores para atuar nessas instituições.

O problema que se coloca, portanto, é que muito pouco se sabe sobre o que caracteriza o profissional que atua em escolas bilíngues, e, consequentemente, sobre quais são os parâmetros que devem orientar a sua formação para a docência nessas instituições. De modo a poder contribuir, ainda que minimamente, para diminuir essa lacuna, neste artigo busco descrever uma investigação cujo objetivo foi refletir sobre o posicionamento discursivo de uma professora que atua em uma escola bilíngue. Para tanto, examinamos sua narrativa gerada a partir de seu retrato linguístico. O estudo em questão foi orientado pela seguinte pergunta de pesquisa: Como a participante da investigação posiciona-se, em sua narrativa, em relação às línguas que compõem o seu repertório linguístico?

Este artigo está dividido em 5 seções: na primeira, denominada introdução, apresento o contexto e introduzo o estudo conduzido; na segunda, discorro acerca do conceito de repertório linguístico; na terceira, delimito a linha metodológica na qual o estudo está situado; na quarta, apresento a análise da narrativa; e na quinta, teço minhas reflexões finais acerca do estudo descrito.

\section{O bilíngue e seu repertório linguístico}

Vários especialistas, tal como Busch (2012), vêm, mais recentemente, enfatizando o fato de que as pesquisas da área de bilinguismo devem focalizar o exame das práticas linguísticas dos indivíduos bilíngues. Desse modo, a distinção entre primeira e segunda língua já não se faz mais necessária porque as categorias de bilinguismo e sujeito bilíngue, criadas a partir da distinção entre primeira e segunda língua, não conseguem explicar as experiências identitárias e as práticas linguísticas experimentadas por sujeitos em sua condição bilíngue. É, nesse ponto, que a introdução da perspectiva derridiana, tal como se apresenta no ensaio $O$ monolinguismo do outro (Derrida, 2001), é considerada valiosa. Nessa obra, Derrida não discorre acerca do conceito de bilinguismo, porém o autor versa acerca das relações do ser humano com sua(s) língua(s) e suas identidades. 
Derrida (2001) não distingue a língua materna da estrangeira. Desse modo, Uphoff (2007, p. 235) aponta que, para o autor "não seria possível atribuir ao falante nativo uma determinada identidade ou um determinado conhecimento linguístico que seria vedado ao falante supostamente não nativo".

Na ótica derridiana, os falantes podem se apropriar, com maior ou menor desenvoltura, das línguas existentes, mas nunca serão capazes de possuí-la completamente. Em consequência, também, não há como sustentar os critérios que costumavam ser usados para descrever a condição bilíngue apresentada pelos autores que se preocuparam com a criação de tipologias ou categorias de bilinguismo e sujeito bilíngue.

Nesse sentido, Busch (2012) defende a noção de repertório linguístico em detrimento das divisões clássicas de primeira e segunda língua. O conceito de repertório linguístico está associado aos trabalhos de Gumperz (1960; 1964) em duas cidades rurais de tamanho mediano, por ele, denominadas comunidades de fala, ${ }^{1}$ isto é,

[...] (grupos humanos caracterizados) por manter interações frequentes e regulares por meio de um conjunto de signos verbais compartilhados, e separada de outros grupos humanos semelhantes por diferenças significativas no uso da linguagem. (Gumperz, 1972, p. 219).

Por sua vez, a noção de repertório verbal de uma comunidade de fala é definida por Gumperz (1964, p. 137) como "a totalidade das formas linguísticas empregadas no curso das interações socialmente significativas" e que contém todos os modos aceitáveis de formular mensagens, por isso, fornecem "as armas para a comunicação diária" (p. 138). Para o autor, o indivíduo faz escolhas relacionadas ao uso de seu recurso linguístico sujeitas a restrições gramaticais e sociais e, por isso, essas escolhas são limitadas por convenções aceitáveis que servem para classificar tipos de expressão, como, por exemplo, formal, técnica, literária e humorística, entre outras.

Busch (2012) propõe a redefinição do conceito de repertório verbal a partir da condição de superdiversidade, termo cunhado por Vertovec (2007), que contribuiu para o debate crítico em torno do multiculturalismo e foi imprescindível para a superação das limitações associadas à utilização da etnicidade como principal fator explicativo da diversidade. O autor, ao invocar a superdiversidade, tem como objetivo enfatizar o fato de que houve um crescimento enorme nas categorias de imigração. Isso ocorreu

1 É preciso apontar que o conceito de "comunidade de fala" vem sendo alvo de críticas, nos últimos anos, por pressupor a existência de uma homogeneidade no interior do grupo social que a comporia, a esse respeito, ver, por exemplo, Martin-Jones; Blackledge e Creese (2012, p. 4). 
não apenas em termos de nacionalidade, etnicidade, língua e religião, mas deu-se, também, em decorrência das diferentes razões para a imigração e dos diferentes padrões e itinerários dos contingentes migratórios.

Segundo Busch (2012), as comunidades de fala tornaram-se temporárias devido às condições da superdiversidade e, com isso, elas estão cada vez mais sujeitas a rápidas mudanças e, além disso, reúnem indivíduos com diferentes repertórios, recursos e práticas comunicativas.

Busch $(2012 ; 2015)$ salienta que para se posicionar para além do conceito de comunidade de fala, deve-se assumir uma perspectiva biográfica que vincule o repertório linguístico do indivíduo à sua trajetória de vida. Outra possibilidade seria assumir uma perspectiva espacial, como proposta por Otsuji e Pennycook (2010), que cunharam o termo "repertório espacial", que é a relação do repertório formado pela trajetória de vida do sujeito com os recursos linguísticos disponíveis em um local específico.

Em consonância ao proposto pelos autores, Blommaert e Backus (2013) entendem o repertório linguístico como uma miscelânea de recursos, habilidades e competências aprendidas por um indivíduo que, por ser móvel, ao longo de sua trajetória de vida, depara-se com situações de aprendizado de língua formais e encontros informais com a língua. Os autores defendem a ideia de que o repertório linguístico reflete a vida do sujeito, que ocorre em um espaço real sociocultural, histórico e político, e que não remete apenas ao seu local de nascimento.

Rymes (2014), por sua vez, defende a ideia de que um repertório comunicativo não é formado apenas pela língua, mas, de igual modo, por elementos não linguísticos ${ }^{2}$, como a forma como o sujeito se veste, a cor de sua pele, o comprimento de seu cabelo, o modo como se senta durante uma entrevista ou o tipo de mala na qual carrega papéis. Segundo a autora, todos esses aspectos podem ter um efeito em como os encontros com a diversidade se revelam e por isso fazem parte do repertório comunicativo do sujeito.

Busch (2015, p. 6) esclarece que os modelos propostos por Blommaert e Backus (2013), Otsuji e Pennycook (2014) e Rymes (2014) compartiIham da noção de uma análise do repertório que é elaborada "a partir da perspectiva de um observador externo". A autora explica que, além dessa perspectiva externa, que é centrada no falante, ela adota a perspectiva do próprio sujeito baseada em suas narrativas autobiográficas, tema que será tratado na seção seguinte deste trabalho.

2 A proposta de Rymes (2014) está relacionada à relevância dos estudos contemporâneos sobre multimodalidade. Jewitt (2009), citada por Liberali et al. (2015, p. 6), aponta para o fato de que "a multimodalidade ressalta a importância da compreensão e análise do repertório de significados formados pelos recursos socialmente moldados ao longo do tempo e culturalmente compartilhados por determinada comunidade". 
Busch (2015, p. 7) propõe que "o conceito de repertório linguístico precisa ser expandido de modo a incluir pelo menos duas outras dimensões: as ideologias linguísticas e o que a autora denomina a experiência vivida da língua". No tocante às ideologias linguísticas, a autora explica que atitudes pessoais em relação à língua são amplamente determinadas pelo valor atribuído a ela ou a uma variedade dela em um espaço social. No caso de repertórios linguísticos, essa ideia está associada ao poder restritivo ou de exclusão das categorizações linguísticas, como, por exemplo, quando falantes de uma língua ou de um modo de falar específico não são reconhecidos ou não se percebem como falantes legítimos dessa língua. Isso pode acontecer não apenas quando se adentra por espaço social no qual as práticas linguísticas e suas regras não são familiares, mas também quando espaços que eram familiares são reconfigurados e, como resultado, políticas linguísticas são modificadas dentro de um curto espaço de tempo.

O conceito de experiência vivida da língua possibilita focalizar a dimensão biográfica do repertório linguístico a fim de reconstruir como o repertório se desenvolve e modifica-se ao longo da vida (Busch, 2015). A autora ensina que:

[...] o que interessa nesse conceito não é o modo pelo qual as habilidades linguísticas são adquiridas e acumuladas ao longo do tempo pelo sujeito; ao invés disso, a expectativa é de que seja possível o resgate de como, por meio de experiências emocionais e corporais, situações dramáticas ou recorrentes de interações com o Outro se tornaram parte do repertório linguístico do sujeito, seja devido a atitudes linguísticas implícitas ou explícitas e a padrões habituais de práticas linguísticas. (Busch, 2015, p. 9).

A esse respeito, Busch (2015) explica que é apenas quando não se reduz a língua à sua dimensão cognitiva e instrumental, mas, ao contrário, dá-se a devida importância à sua natureza, essencialmente, intersubjetiva e social e à sua dimensão emocional e corpórea, que questões acerca de atitudes pessoais pertinentes à língua podem ser adequadamente formuladas.

O conceito de experiência vivida da língua proposto por Busch tem base na fenomenologia da percepção desenvolvida na década de 1940, por Merleau-Ponty. Para o autor, como descrito por Busch (2015), a língua é um fenômeno essencialmente corpóreo, uma vez que, assim como o gesto e a emoção, ela "é primeiramente, e acima de tudo, um posicionamento do sujeito em relação ao mundo" - e é apenas então a língua se torna "um ato cognitivo de representação e simbolização" (p. 10). Desse modo, a autora reivindica que, ao conceber a língua como parte dessa memória corpórea, é possível entender o repertório, em sua dimensão biográfica, "como uma estrutura que carrega traços de experiências passadas de interações situadas e de práticas linguísticas cotidianas derivadas dessas experiências" (p. 11). 
Busch (2015) faz uso do conceito de cronotopo, que é a interligação fundamental das relações temporais e espaciais no discurso, conforme proposto por Bakhtin (1981) para explicar a dimensão multifacetada do repertório. A esse respeito, Blommaert e De Fina (2015) explicam que essas configurações cronotópicas permitem ou sancionam modos particulares de comportamentos específicos a partir de escalas de distribuição que os definem como "positivos, desejáveis ou compulsórios" (p. 3). Isso acontece, segundo os autores, por meio de escalas de indexicalização dos modos cronotopicamente relevantes e que assumem um certo valor reconhecível dentro de uma configuração específica de tempo-espaço.

Os conceitos de cronotopo e escalas de indexicalização implicam no desenvolvimento de um conjunto complexo de recursos multimodais que permitem ao sujeito sua inserção em práticas sociais diversas. Blommaert (2006) esclarece que o construto analítico de indexicalização é importante porque indica como performances discursivas de um determinado sujeito sinalizam discursos construídos social, histórica e coletivamente e que permeiam a realidade social.

No mundo contemporâneo, o sujeito precisa mobilizar seus recursos linguísticos e sociolinguísticos, ao distanciar-se de usos de linguagem "sedentários" ou "territorializados" (Blommaert, 2010, pp. 4-5), a fim de se conectar aos complexos e fluidos contextos sociolinguísticos da atualidade. Desse modo, entende-se que a linguagem se move juntamente com os sujeitos pelo tempo e espaço e, assim, transforma-se em uma poderosa ferramenta para a mobilidade (Blommaert \& Dong, 2007). Blommaert (2010, p. 32), a respeito disso, aduz:
[...] a mobilidade semiótica tem todos os tipos de efeitos sobre os sinais que estão envolvidos em tal mobilidade. Esses processos precisam ser compreendidos porque eles constituem o cerne da globalização como um fenômeno sociolinguístico. No contexto da globalização, recursos linguísticos alteram o valor, função, propriedade e assim por diante, porque eles podem ser inseridos nos padrões de mobilidade.

Dessa maneira, os recursos que fazem parte do repertório linguístico do sujeito envolvem variedades linguísticas, registros, gêneros, modalidades e escolha de línguas, vocabulário e estruturas. A escolha de língua por sujeitos bilíngues, por exemplo, está relacionada à percepção de construtos ideológicos e institucionais e aos modos de uso da linguagem.

Em consonância com o proposto por Blommaert (2010), Busch (2015, p. 14) desconstrói a ideia de que "o repertório é um conjunto de competências, um tipo de caixa de ferramentas, da qual selecionamos a língua certa, ou o código correto para cada contexto ou situação". De acordo com esta autora, a extensão das escolhas acessíveis para um falante não é limitada, apenas, por regras gramaticais e conhecimentos das convenções 
sociais; ao invés disso, línguas ou modos de falar particulares podem ter fortes conotações emocionais ou ideológicas que não estão disponíveis ou estão parcialmente disponíveis em momentos específicos. Busch (2015, p. 14) enfatiza, assim, que o repertório não "é determinado apenas pelos recursos linguísticos que temos, mas também por aqueles que não temos, e esses podem se tornar visíveis em determinadas situações como uma lacuna, uma ameaça ou um desejo".

Busch (2015, p. 14) explica que o repertório linguístico pode ser entendido como um "domínio heteroglóssico de limites e potencialidades". Nele, diferentes línguas e modos de falar revezam-se, interferem-se mutuamente e entrelaçam-se para formar algo novo, mas, de uma forma ou de outra, eles estão sempre lá. A autora complementa, ao citar Bakhtin, que devido ao fato de a língua ser dialógica, uma vez que se encontra na fronteira entre o eu e o Outro, o repertório linguístico reflete "a coexistência sincrônica de diferentes espaços sociais nos quais nós participamos como falantes, e aponta diacronicamente para diferentes níveis de tempo" (p. 14). Para Busch, o repertório não se direciona somente para o passado de nossa biografia linguística, "que deixou para trás seus traços e cicatrizes", mas converge-se, também, para o futuro, antecipando e projetando "situações futuras e eventos que estamos nos preparando para enfrentar" (2015, p. 14).

\section{Metodologia}

A professora-participante da pesquisa foi convidada a desenhar seu "retrato linguístico", seguindo o que preconiza Busch³ (2006; 2010). A expectativa era que esse desenho e sua posterior narração fornecesse elementos para que eu pudesse responder à pergunta que norteou este estudo: como a participante da investigação posiciona-se, em sua narrativa, em relação às línguas que compõem o seu repertório linguístico?

Busch (2006), que desenvolve pesquisas com biografias linguísticas em contextos multilíngues, afirma que abordagens biográficas podem fazer uma mediação entre um nível da sociolinguística interessado nos papéis e nas funções das línguas envolvidas em um contexto social mais abrangente e um contexto menor, visto por um ângulo individual. Além disso, a autora ressalta que essa abordagem revela como:

3 É preciso, no entanto, enfatizar, que, diferentemente do proposto por Busch (2006), a professora participante não recebeu uma silhueta pronta; ao contrário, foi convidada a representar-se livremente por meio de um desenho, nele, alocando as línguas que a constituem. 
[...] os sujeitos experimentam o contexto social mais amplo e as políticas linguísticas nas quais se desenvolvem as práticas linguísticas, as ambições e os desejos relacionados as imagens de si como sujeito falante de determinadas línguas. (p. 9).

Nesse caso, os estudos biográficos podem ocupar um nível intermediário entre uma análise sociológica do contexto mais amplo e o nível menor de um estudo de caso particular.

A partir de seus estudos, Busch (2006, p. 9) aponta para o fato de que as autobiografias se apoiam em casos individuais. No entanto, seu interesse primeiro "não é a singularidade de uma história de vida particular, mas antes, as dimensões sociais das práticas linguísticas que casos singulares ajudam a revelar". A autora recorre, então, a Bourdieu (1982), que defende que "o valor atribuído a uma prática linguística particular não pode ser entendido separadamente da pessoa que emprega a língua e nem das relações sociais nas quais essa pessoa está engajada" (Busch, 2006, p. 9).

Busch (2006) explica que, na década de 1990, escolas europeias que eram compostas por alunos dos mais diversos países, devido à forte corrente migratória para Europa, iniciaram um trabalho com retratos linguísticos que tinham como objetivo visualizar e entender os recursos linguísticos utilizados por seus alunos. Esse trabalho consistia em solicitar aos alunos que colorissem silhuetas de corpos com diferentes cores que simbolizavam as línguas que essas crianças falavam. A autora esclarece que esse trabalho com desenhos foi, primeiramente, aplicado a crianças e, posteriormente, utilizado com professores africanos em um curso cujo objetivo era discutir abordagens para o ensino de classes multilíngues.

Busch $(2006 ; 2010)$ salienta que o trabalho com narrativas biográficas multimodais pode fazer com que o falante se conscientize do potencial de seus recursos linguísticos. O fato de haver uma mudança do modo de representação - da palavra oral/escrita para o visual - muda o foco de atenção e contribui para:

$$
\begin{aligned}
& \text { [...] descontruir categorias internalizadas, refletir sobre práticas perso- } \\
& \text { nificadas e para gerar narrativas que são menos fixadas por expecta- } \\
& \text { tivas de gênero. Enquanto que a lógica da palavra se caracteriza por } \\
& \text { uma sequência linear presa ao tempo, a representação visual é caracte- } \\
& \text { rizada pelo espaço e pela simultaneidade, além de demandar atenção } \\
& \text { para os modos pelos quais os diferentes componentes da imagem se } \\
& \text { relacionam entre si. (Busch, 2010, p. 286). }
\end{aligned}
$$

De acordo com a autora, retratos linguísticos, além disso, enfatizam o presente ao invés de enfatizar o caminho que o sujeito percorreu até o momento em que realizou a tarefa de colorir o seu desenho. Assim, ao adotar esse tipo de procedimento de geração de dados na pesquisa aqui 
relatada, parti do pressuposto que ele poderia contribuir para uma maior compreensão de como a professora-participante do estudo posiciona-se em relação ao seu repertório linguístico.

Após ter elaborado seu desenho, solicitei à professora-participante que narrasse suas interpretações acerca da alocação que fizera das línguas de seu repertório linguístico na imagem de seu "corpo". Essa narrativa, também, foi gravada em áudio e, posteriormente, transcrita para a análise.

A adoção desse terceiro procedimento metodológico de geração de dados deveu-se porque, segundo Busch (2006), a forma pela qual as várias línguas são representadas, graficamente, em uma silhueta humana evidenciam significados particulares que são revelados, apenas, quando seus autores as explicam e interpretam.

Segundo Busch (2006), as narrativas geradas a partir dos desenhos, geralmente, referem-se ao contexto no qual os sujeitos estão inseridos e trazem informações sobre a sua visão de mundo, sua afiliação a grupos sociais particulares, seus laços com certos ambientes culturais e posições políticas.

\section{A professora participante}

Carla é formada em pedagogia por uma universidade estadual paulista, Começou a atuar como assistente em uma escolar bilíngue logo que retornou ao Brasil de um intercâmbio realizado nos EUA para aperfeiçoar seu inglês. À época da geração de dados, Carla ministrava aulas em inglês para uma turma de alunos que ingressaram na escola com 1 ano de idade. Ela trabalhava na escola em questão há 10 anos. Além de seu trabalho como docente, a professora, também, auxiliava a coordenação da instituição em assuntos específicos relacionados ao cotidiano escolar.

\section{Procedimentos de análise dos dados}

A narrativa gerada a partir do retrato linguístico foi analisada tendo em mente alguns dos postulados defendidos por Worhtam (2001) a respeito dos posicionamentos interacionais que emergem das narrativas. Segundo Bizon (2013, p. 88), "o posicionamento assume papel central na compreensão de nossas performances discursivo-identitárias e alteridades e, por conseguinte, na compreensão das realidades sociais que constituem a contemporaneidade".

Neste estudo, mobilizei cinco tipos de pistas indexicalizadoras de vozes e indicativas de posicionamentos interacionais propostos por Wortham (2001) - e discutidas na seção 3.2 - que emergiram na/da narrativa: 
(1) referência e predicação, (2) descritores metapragmáticos, (3) citação, (4) índices avaliativos e (5) modalizadores epistêmicos. Essas pistas indexicalizadoras estão, para melhor visualização, alocadas no quadro a seguir:

Quadro 1 - Pistas Indexicalizadoras utilizadas na análise de dados

\begin{tabular}{|c|c|}
\hline Referência e predicação & $\begin{array}{l}\text { Seleção de coisas no mundo e caracterização nas histórias } \\
\text { que conta, como, por exemplo, o uso de adjetivos. }\end{array}$ \\
\hline Descritores metapragmáticos & $\begin{array}{l}\text { Inclusão de verbos metapragmáticos de enunciação } \\
\text { para referência e caracterização da maneira como } \\
\text { alguma coisa foi dita, avaliando-a, como, por exemplo, } \\
\text { verbos declarativos, como "falar", "dizer", "alegar". }\end{array}$ \\
\hline Citação & $\begin{array}{l}\text { Referência a um falante citado, ao seu } \\
\text { enunciado e ao verbo metapragmático utilizado } \\
\text { para caracterizar o evento de fala. }\end{array}$ \\
\hline Índices avaliativos & $\begin{array}{l}\text { Expressões ou modos de falar associados a } \\
\text { determinados grupos de pessoas, que indexicalizam } \\
\text { o lugar social do narrador e/ou da personagem, } \\
\text { suas ocupações, origens regionais, gênero, etc. }\end{array}$ \\
\hline Modalização epistêmica & $\begin{array}{l}\text { Modalizadores epistêmicos são expressões } \\
\text { formulaicas e tempos verbais utilizados para expressar } \\
\text { o maior ou menor acesso epistêmico que narrador } \\
\text { e personagens têm no evento de narrar e no evento } \\
\text { narrado, como por exemplo "era uma vez". }\end{array}$ \\
\hline
\end{tabular}

Fonte: adaptado de Wortham (2001)

A partir da análise da narrativa, ficou nítido que a professora participante fez uso de figuras de linguagem para narrar seu posicionamento em relação ao seu repertório linguístico. Dessa forma, fez-se necessário, também, considerar as figuras de linguagem como pistas indexicalizadoras, assim como o fez Bizon (2013), em sua tese de doutoramento. Bizon (2013, p. 110) menciona Bauman (1977) e Wortham (2001) para salientar a "notória importância que a utilização de figuras de linguagem pode assumir na construção das narrativas". Além disso, ressalta que esses recursos "iluminam o cenário em foco na narrativa e chamam a atenção para determinadas cenas, contribuindo para o vozeamento e ventrilocução de narradores e personagens" (Bizon, 2013, p. 110). Na narrativa gerada neste estudo, a professora utilizou imagens que se apoiaram em metáforas, comparações, hipérboles e antíteses. Sendo assim, ao quadro anteriormente apresentado, adiciono agora as figuras de linguagem como mais uma das pistas indexicalizadoras de vozes que utilizei para indicar os posicionamentos da narradora referente à questão que norteia este estudo: 
Quadro 2 - Pista Indexicalizadora complementar construída a partir da análise das narrativas

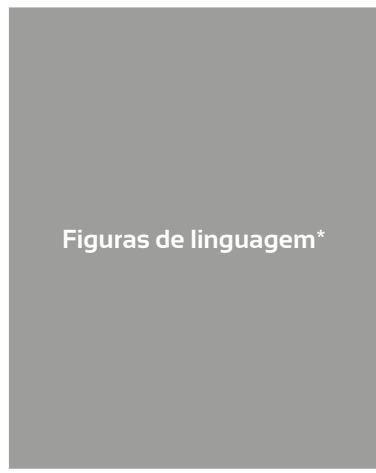

As figuras de linguagem são recursos ou instrumentos que se podem empregar na fala ou na escrita para deixar a frase ou mensagem mais expressiva ao ser transmitida.

Alguns exemplos de figuras de linguagem utilizadas nas narrações deste estudo são:

- Metáfora: emprego de uma palavra semelhante em lugar de outra palavra ou termo que possui um significado diferente do uso comum.

- Comparação: emprego de uma palavra para se comparar ou mesmo qualificar aquilo a que se refere por meio do uso de conectivos (como, tal, assim, qual, etc.).

- Hipérbole: emprego de um exagero proposital.

- Antítese: emprego de palavras que expressam o contrário.

*Disponível em: <https://www.meusdicionarios.com.br/figuras-de-linguagem>.

Fonte: elaboração própria

\section{A narrativa de Carla}

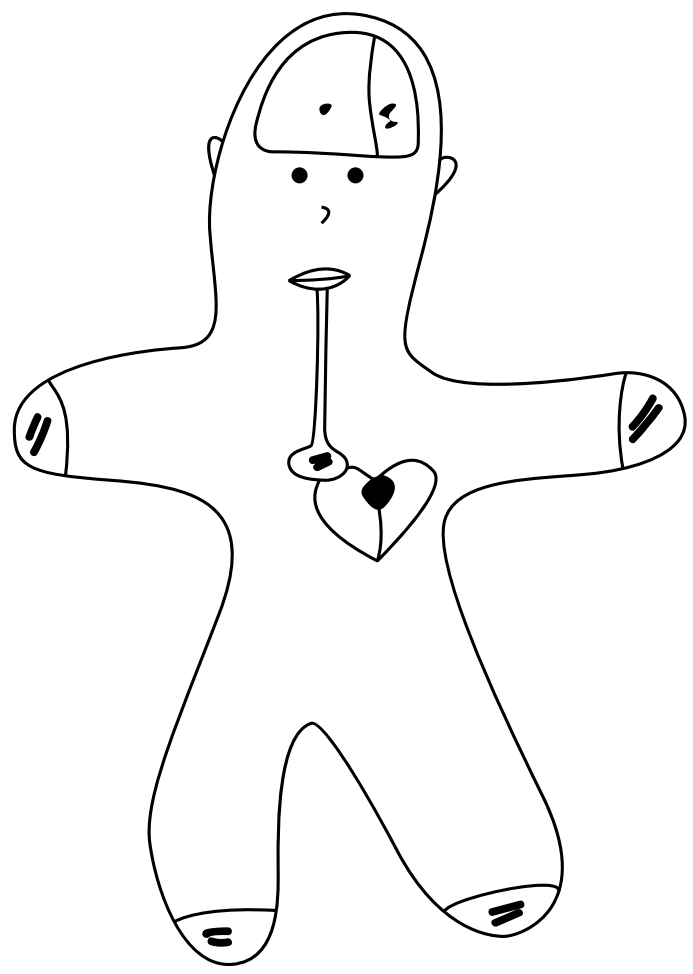

Figura 1 - "Retrato linguístico" de Carla Fonte: dados da pesquisa 
Ao narrar seu retrato linguístico, exposto na figura 1, Carla encena uma performance narrativa que traz à tona suas memórias de quando aprendeu inglês:

\section{Excerto 1. O bilinguismo de Carla}

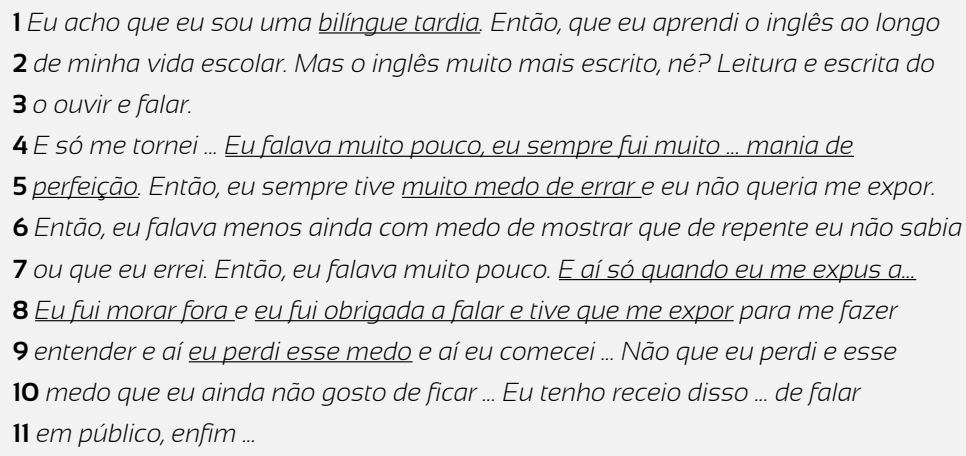

Fonte: participante da pesquisa

Carla aborda em sua narrativa discursos que circulam no senso comum sobre o que é ser bilíngue (linha 1-3) e sobre processo de aprendizagem de uma língua estrangeira (linha 8-9). Para tanto, Carla, ao narrar seu retrato linguístico, traz à tona memórias sobre como se constituiu falante da língua inglesa.

Relativamente ao que é ser bilíngue, Carla, ao evocar suas memórias sobre quando e como aprendeu inglês, define-se como uma bilíngue tardia (linha 1), o que sugere uma citação indireta a autores, como, por exemplo, Hamers e Blanc (2000). Esses autores debruçaram-se sobre a criação de tipologias e categorias que tiveram como objetivo a abordagem do bilinguismo como um fenômeno multidimensional. Hamers e Blanc apontam em sua classificação, na terceira dimensão de bilinguismo proposta, a idade de aquisição das línguas. Carla, ao denominar-se bilíngue tardia, uma vez que relata que aprendeu inglês ao longo de sua vida escolar (linha 2), remete-se ao bilinguismo adolescente ou adulto proposto por Hamers e Blanc, ou seja, a aquisição da segunda língua na idade adulta ou durante a adolescência.

Ao fazer uso do termo bilíngue tardia, Carla entextualiza os discursos amplamente difundidos por alguns autores que utilizam o falante nativo como modelo de conhecimento linguístico a ser alcançado pelo bilíngue. Desse modo, Carla, à luz de autores como Hamers e Blanc, faz circular a noção de bilíngue tardia em contraposição ao período no qual falantes nativos aprendem uma língua - a primeira infância. 
Nesse excerto, a narradora predica a si mesma em seu processo de aprendizado da língua inglesa: eu falava muito pouco (linha 4), eu sempre fui muito ... mania de perfeição (linha 5) e eu sempre tive muito medo de errar (linha 5). Dessa forma, Carla nos sinaliza que esse processo foi penoso e difícil para ela devido ao seu medo de cometer erros ao falar em uma língua que julgava não dominar.

Em sua performance narrativa, Carla aponta que apenas quando foi morar fora do Brasil (linha 9) que perdeu o medo de falar inglês. O descritor metapragmático "perdi esse medo" indexicaliza o processo vivenciado pela narradora para se tornar falante da língua inglesa. Os descritores metapragmáticos incluem os denominados verbos do dizer, que são aqueles que descrevem exemplos de uso de língua. Carla, nesse excerto, vozeia seu próprio falar em língua inglesa e descreve a relação que estabeleceu com a utilização oral do inglês. Como apregoa o senso comum, Carla coaduna com a ideia de que morar fora do país é imprescindível para o aprendizado de uma língua estrangeira.

Nesse sentido, a narradora, ao afirmar: eu fui obrigada a falar e tive que me expor ... (linha 9 e 10), reforça seu posicionamento de que foi apenas quando foi morar no exterior que se tornou falante de língua inglesa e perdeu o medo de falar. Nesse trecho, Carla expressa uma avaliação sobre o valor de verdade da proposiçãa, comprometendo-se com o conteúdo expresso, ou seja, com o fato de que foi apenas o morar no exterior que a tornou falante de língua inglesa.

Na linha 7, a narradora não completa sua frase ( $E$ aí foi só quando eu me expus a ...) e esta lacuna possibilita sugerir complementos para sua narrativa. A linha de raciocínio proposta pela participante leva a crer que a frase poderia ser completada com a palavra "nativos", pois essa figura ocupa posição central na narrativa de Carla que faz uso de seu campo conceitual para se definir como bilíngue.

É possível o levantamento de variadas hipóteses que poderiam explicar o motivo pelo qual Carla decide não completar sua frase: estaria Carla consciente de toda a problemática que envolve o conceito de falante nativo? Carla é uma professora que busca atualização constante e, como relata em sua narrativa, a própria escola na qual trabalha oferece diversos cursos para que seus professores se aperfeiçoem. Desse modo, uma das hipóteses possíveis é a de que, embora Carla entenda conceitualmente a discussão proposta acerca do conceito de falante nativo como modelo e parâmetro que balize o entendimento e a mensuração de competências de indivíduos bilíngues, ainda é difícil para a participante se distanciar dessa noção ao narrar seu próprio bilinguismo. Essa visão de bilinguismo, 
que tem como modelo o falante nativo, também ressurge na narrativa de Carla quando ela nos narra o modo pelo qual alocou as línguas em seu corpo em seu desenho:

\section{Excerto 2. Os "dominios" de Carla}

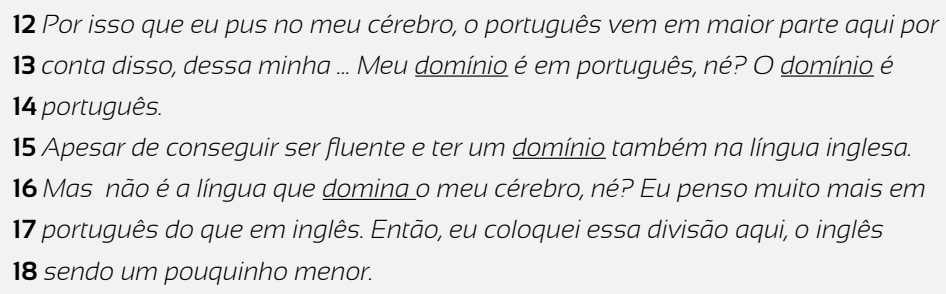

Fonte: participante da pesquisa

Nesse excerto, Carla faz uso de uma figura de linguagem, metáfora - eu pus no meu cérebro (linha 12) - para explicar o que define como domínio em cada uma das línguas (linha 13, 14 e 15). O domínio do inglês é um dos aspectos mais destacados pelo mercado de trabalho atual a partir do discurso capitalista. Há de se ter professores que dominem o inglês para que esses façam com que seus alunos também dominem a língua inglesa e, com isso, possam ingressar no competitivo mercado de trabalho. Carla textualiza essa ideia de dominar línguas e confina-as em um lugar determinado, como se faz com animais a serem dominados, por exemplo. O local escolhido por Carla para confinar suas línguas foi o cérebro, que tem uma relação com o desenvolvimento cognitivo e, consequentemente, com a aprendizagem de novos conceitos.

Carla parece apoiar-se no conceito de que língua é apenas um sistema de estruturas que o falante deve apreender, ou dominar, como afirma. Carla apoia-se no que entende por competência linguística e, nesse ponto, parece comparar suas competências com as de um falante nativo monolíngue. Dessa forma, refere que seu domínio é em português (linha 12), embora consiga ser fluente e ter um domínio, também, na língua inglesa (linha 14). Porém, Busch (2015) desconstrói a ideia de que o repertório é um conjunto de competências, um tipo de caixa de ferramentas da qual selecionamos a língua certa ou o código correto para cada contexto ou situação. De acordo com a autora, a extensão das escolhas acessíveis para um falante não é limitada, apenas, por regras gramaticais e conhecimentos das convenções sociais; ao invés disso, línguas ou modos de falar particulares podem ter fortes conotações emocionais ou ideológicas que não estão disponíveis ou estão parcialmente disponíveis em momentos específicos. 
Ao desenhar suas línguas lado a lado em seu cérebro, porém compartimentalizadas em espaços separados, Carla parece revelar sua visão monoglóssica de língua. A narradora compara o tamanho (linha 17) do domínio de suas línguas e predica o inglês como menor (linha 18), uma vez que entende que seu domínio é menor nessa língua.

Sua narrativa permite inferir que Carla entende o funcionamento de suas línguas como mecanismos que operam de forma independente. A participante parece desconhecer o fato de que, em seu repertório linguístico, diferentes línguas e modos de falar se revezam, interferem-se mutuamente e entrelaçam-se para formar algo novo. É possível dizer que, muito provavelmente, Carla, de igual modo, desconheça a noção de repertório linguístico que, como Busch (2012) alerta, foi concebida em detrimento das divisões clássicas de primeira e segunda língua.

Em sua performance discursiva sobre seu repertório linguístico, a narradora posiciona-se de modo que faz uso de descritores metapragmáticos para sinalizar sua relação de insegurança ao expor-se em ambas as línguas, como se pode observar no excerto que segue:

\section{Excerto 3. A relaçao de Carla com o inglês}

19 E ai por conta desse receio de ter que falar em público, eu venho trabalhando

20 isso mais, cada vez mais, ainda mais agora como assistente de coordenação,

21 né? Eu tenho que me expor que falar com os pais e fazer reuniões $e$

22 apresentar trabalhos. Eu tenho trabalhado isso melhor, mas é em português.

23 Então, eu me controlo muito mais falando em português. Em inglês ainda vem

24 um frio na barriga. Então, eu pus o meu estômago em inglês que isso me dá

25 um ... Eu transpiro.

Fonte: participante da pesquisa

A narradora utiliza os descritores metapragmáticos - "tenho que me expor, fazer reuniões e apresentar trabalhos" (linha 21 e 22) - para descrever algumas de suas obrigações relacionadas ao falar em público exigidas em função do cargo de assistente de coordenação.

O verbo "controlar", outro descritor metapragmático, do enunciado "eu me controlo mais falando português" (linha 23), também marca seu posicionamento em relação à sua constituição como bilíngue. A narradora parece entextualizar os discursos acerca do querer controlar totalmente a língua que se fala, ou seja, não hesitar, ter fluidez, não cometer erros gramaticais e lexicais e dar respostas sempre corretas. Ao referir-se ao inglês, Carla utiliza a figura de linguagem, "frio na barriga" (linha 24) e faz uso do descritor metapragmático "eu transpiro" (linha 25) para expressar como se sente ao falar inglês em público. 
É possível inferir, pelo seu discurso, que a "transpiração" da narradora ao falar inglês em público ocorre uma vez que ela não se controla em inglês como ela se controla em português. Esse não controle em inglês causaria, em Carla, um desconforto tão grande que a faria transpirar. Carla descreve esse desconforto por meio da figura de linguagem "um frio na barriga" (linha 24). Esse desejo de controlar a língua que se fala é cultural e é pautado na crença de que o papel da escola bilíngue seria o de oferecer ao aluno a possibilidade do "controle pleno" do inglês e do português. Desse modo, não seria permitido à narradora, que é a professora que ensinaria esse controle ao aluno, um "não controle em inglês".

Ao posicionar-se em relação ao seu repertório linguístico, a narradora parece reduzir a língua à sua dimensão cognitiva e instrumental e, dessa maneira, passível de controle. No entanto, Carla parece reivindicar a dimensão corpórea de seu repertório linguístico ao relacioná-lo com o verbo "transpirar". Busch (2015) explica que o importante no conceito de repertório linguístico não é o modo pelo qual as habilidades linguísticas são adquiridas e acumuladas ao longo do tempo; ao invés disso, há a expectativa de traçar como, por meio de experiências emocionais e corporais, situações dramáticas ou recorrentes de interações com o Outro tornam-se parte de seu repertório. No caso da narradora, a experiência corporal e emocional de transpirar na interação com o Outro por meio da língua inglesa se tornou parte de seu repertório. Somando-se a isso, Carla narra, também, sua ligação emocional com o inglês como se pode observar no excerto 4 :

\section{Excerto 4. O vínculo com o inglês}

260 meu coração, então, porque eu me apaixonei por essa língua. Mesmo não

$\mathbf{2 7}$ sendo ... tendo nenhuma referência familiar né? Meus pais não falam inglês.

28 Então, na minha família, acredito que só eu falo inglês. Eles podem entender

29 alguma coisinha, mas é muito, muito pouco. Então, essa língua tomou também o

30 meu coração. O meu emocional, né? Essa ... Criei um vínculo com essa língua.

31 Então, eu ponho metade em português e metade em inglês no coração.

\section{Fonte: participante da pesquisa}

Em seu desenho, Carla posiciona a língua inglesa e portuguesa em seu coração. Ao prosseguir sua narração, diferentemente da visão sistêmica de língua que apresenta nos excertos 26 e 27, a narradora sinaliza uma relação afetiva com a língua inglesa ao enunciar: eu me apaixonei por essa língua (linha 26), essa língua tomou também meu coração (linha 29-30) e criei um vínculo com essa língua (linha 30). 
Nessa performance discursiva, a narradora, para explicar sua paixão pelo inglês, posiciona-se marcando a distância de sua família ao utilizar os modalizadores epistêmicos: nenhuma referência familiar (linha 27) e só eu falo inglês (linha 28). Faz uso também de uma figura de linguagem como a hipérbole muito, muito pouco (linha 29) para marcar seu distanciamento de sua família no que se refere ao conhecimento da língua inglesa. Carla afirma, então, ser a única falante de língua inglesa em sua família.

Pode-se traçar um paralelo do enunciado por Carla, quando explica que é a única que fala inglês em sua família, ao conceito de experiência vivida da língua proposto por Busch (2015). Essa noção possibilita focalizar a dimensão biográfica do repertório linguístico a fim de reconstruir como o repertório se desenvolve e modifica-se ao longo da vida. Desse modo, a narradora adquiriu, ao longo de sua trajetória, recursos linguísticos e sociolinguísticos que a distanciaram dos usos de linguagem sedentários de sua família (Blommaert, 2010) a fim de conectar-se aos complexos e fluidos contextos sociolinguísticos da atualidade ao aprender inglês. Assim, é possível afirmar que, para a narradora, o inglês moveu-se pelo tempo e espaço de sua vida e transformou-se em uma ferramenta para a mobilidade, pois é, por meio dessa língua, que Carla ascendeu profissionalmente, como explica na passagem a seguir:

\section{Excerto 5. Possibilidades de seu repertório linguístico}

32 A partir do momento que eu vivi essa experiência e tenho o inglês próximo,

33 então, eu coloquei nos pés que eu pude a partir do inglês eu acho que eu pude

34 conseguir conhecer mais coisas, nesse sentido de caminhar de se eu quiser

35 ir para qualquer país que tenha, né? O português, acho que a gente é muito

36 limitado sabendo falar só o portuquês e no inglês a gente consegue ir pra ... se

37 comunicar geral, por isso que eu pus no pé, que eu consigo ir para outros

38 lugares e ser entendida.

Fonte: participante da pesquisa

Nessa passagem, Carla posiciona-se quanto à sua experiência de morar fora do Brasil e predica o inglês como próximo (linha 32) a partir dessa vivência no exterior.

Ao posicionar o inglês em seus pés, Carla explica que foi, por meio dessa língua, que conseguiu conhecer mais coisas (linha 34). Nesse ponto, Carla relaciona a possibilidade de maior conhecimento com a possibilidade de caminhar (linha 34), de deslocar-se para outros países (linha 35), de conseguir ir ... (linha 37). Para Carla, a proximidade do inglês assume uma configuração cronotópica positiva e desejável (Blommaert \& De Fina, 
2015) que lhe permite se inserir em práticas sociais diversas que não seriam possíveis por meio do português - "O português, acho que a gente é muito limitado sabendo falar só o português" (linha 35-36).

Nessa direção, Carla faz uso de índices linguísticos para sinalizar a ideia de deslocar-se, de ir para mais longe por meio da língua inglesa. A esse respeito, Blommaert e Dong (2007) ressaltam que a língua pode ser uma ferramenta para a mobilidade. Os autores explicam que, no contexto da globalização, recursos linguísticos alteram o valor e a função porque podem ser inseridos nos padrões de mobilidade. Assim, Carla faz circular em seu discurso a espetacularização midiática (Debord, 1997) sobre os acontecimentos envolvendo a língua inglesa como a língua com "cotação" mais alta no mundo atual.

\section{Considerações finais}

Retomo, brevemente, os principais posicionamentos construídos pela professora em relação ao seu repertório linguístico. O exame da narrativa produzida por Carla revela que ela se posicionou como bilíngue tardia (Hamers; Blanc, 2000), apoiando-se em uma visão monoglóssica de língua. É importante salientar que as dimensões propostas por Hamers e Blanc (2000) esbarram na dificuldade de tentar colocar os sujeitos bilíngues em categorias pré-fixadas que têm como base uma visão monoglóssica de língua.

Embora essa visão, que concebe as línguas que constituem o sujeito bilíngue como espaços autônomos e independentes, não seja a defendida neste estudo, a narradora em seu discurso parece se aproximar da dimensão proposta pelos autores que traça uma distinção a partir da idade de aquisição de línguas pelo sujeito.

Utilizo aqui a categorização proposta por Hamers e Blanc (2000) apenas para problematizar tipologias e categorizações calcadas em uma visão monoglóssica de língua que compara as competências linguísticas dos bilíngues com as de falantes monolíngues das línguas em questão. De outra feita, reitero a ideia defendida neste estudo de que o bilinguismo seja considerado a partir de uma visão heteroglóssica, pela qual se considera que o sujeito bilíngue se constitui na imbricação de ambas as suas línguas.

Essa participante vozeou, por vezes, noções que fazem parte do discurso popular como, por exemplo, a ideia de que só é possível aprender inglês quando se mora fora do país e tem-se contato com falantes nativos. Além disso, Carla fez uso de diversas figuras de linguagem para retratar sua relação com as línguas que compõem seu repertório linguístico. A esse respeito, Carla posicionou a língua inglesa como uma língua que a faz "transpirar", ou seja, a narradora ainda não exerceria o "controle" sobre a língua inglesa que julga necessário. Somando-se a isso, a língua inglesa 
foi por ela posicionada como uma ferramenta para a mobilidade, isto é, uma língua que, como Carla parece entender, permite deslocamentos impossíveis de serem realizados por meio da língua portuguesa.

As angústias, dúvidas e possíveis certezas reveladas a partir do posicionamento de Carla em relação ao seu repertório linguístico possibilitam elencar algumas demandas na formação desses profissionais e, consequentemente, a necessidade premente de realização de pesquisas que versem sobre essa questão no cenário brasileiro.

Primeiramente, há a necessidade da compreensão - por parte não apenas dos professores que atuam em contextos multilíngues, mas também dessas comunidades escolares, - do conceito de repertório linguístico em detrimento de divisões clássicas de línguas e para além de conhecimentos de cunho estritamente linguísticos. Há de se entender que o repertório linguístico compreende dimensões corpóreas e emocionais (Busch, 2015) e que abrange elementos não linguísticos, como os propostos por Rymes (2014). Esse entendimento elucidaria, na professora deste estudo, a sensação de "falta" que marca seu posicionamento em relação ao seu repertório. Ademais, por meio da compreensão do conceito de repertório, práticas translíngues seriam mais amplamente aceitas entre os professores que lidam com alunos bilíngues como o modo natural de interação desses sujeitos. Com isso, ideias que remetem ao ensino compartimentalizado das línguas em espaços monoglóssicos protegidos não mais se sustentariam, e, por conseguinte, assistir-se-ia a uma nova configuração dessas escolas bilíngues, que se veriam na função de planejar intencionalmente espaços que propiciassem aos alunos a utilização de todo o seu repertório linguístico para a construção de conhecimento.

\section{Referências}

Bakhtin, M. (1981). Forms of time and the chronotope in the novel. In: M. Holquist (Org.). The dialogic imagination: four essays by M. M. Bakhtin. (pp 88-258). Austin: University of Texas Press.

Bizon, A. (2013). Narrando o exame celpe-bras e o Convênio Pec-G: a construção de territorialidades em tempos de internacionalização. 2013. 415 f. Tese (Doutorado em Linguística Aplicada) - Universidade Estadual de Campinas (Unicamp), Campinas.

Blommaert, J. (2006). Sociolinguistic scales. Working Papers in Urban Language \& Literacies, paper 37. Disponível em <https://www.kcl.ac.uk/ sspp/departments/education/research/Research-Centres/ldc/publications/workingpapers/the-papers/37.pdf > .

Blommaert, J. (2010). The sociolinguistics of globalization. Cambridge: Cambridge University Press.

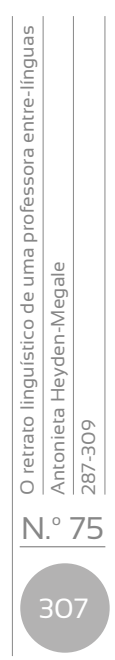


Blommaert, J. \& Backus, A. (2013). Superdiverse repertoires and the individual. In I. Saint-Georges \& J. J. Weber (Eds.). Multilingualism and Multimodality: Current Challenges for Educational Studies. Rotterdam: Sense Publishers.

Blommaert, J \& Dong, J. (2007). Ethnographic fieldwork: a beginner's guide. Bristol: Short Run Press.Blommaert, J. \& De Fina, A. (2015). Chronotopic identities: On the timespace organization of who we are. Holanda: Babylon, Center for the Study of Superdiversity. Tilburg Papers on Cultural Studies, paper 153. Disponível em <https:// www.tilburguniversity.edu/upload/ba249987-6ece-44d2-b96b-3fc329713d59_TPCS_153_Blommaert-DeFina.pdf> Acesso em: 14 abr. 2017.

Busch, B. (2006). Language biographies - approaches to multilingualism in education and linguistic research. In B. Busch; A. Jardine \& A. Tjoutuku. Language biographies for multilingual learning. PREAESA Occasional Papers 24. Cape Town: PREAESA. Disponível em <http:// paulroos.co.za/wpcontent/ blogs.dir/22/files/2012/07/Paper24.pdf>.

Busch, B. (2010). School language profiles: valorizing linguistic resources in heteroglossic situations in South Africa. Language and education, 24 (4), pp. 283-295.

Busch, B. (2012). The Linguistic Repertoire Revisited. Applied Linguistics, 33 (5), pp. 503-523.

Busch, B. (2015). Linguistic repertoire and Spracherleben, the lived experience of language. Working Papers in Urban Language \& Literacies. Paper 148. Disponível em <https://www.kcl.ac.uk/sspp/departments/ education/research/Research-Centres/ldc/publications/workingpapers/abstracts/WP148-Busch-2015--Linguistic-repertoire-and-Spracherleben,-the-lived-experience-of-language.aspx>. Acesso em: 22 set. 2016.

Derrida, J. (2001). O monolinguismo do Outro ou a prótese da origem. Trad. F. Berardo. Porto: Campo das Letras.

Gumperz, J. (1960). Formal and informal standards in Hindi regional language area. In: C. A. Fergunson.; J. Gumperz (Orgs.). Linguistic Diversity in South Asia. International Journal of American Linguistics, III., pp. 92-11.

Gumperz, J. (1964). Linguistic and social interaction in two communities, American Anthropologist, v. 66, n. 6/2, pp. 137-53.

Gumperz, J. (1972). The speech community. In: P. P. Giglioli (Org.). Language and social context. (pp. 219-231). Middlesex: Penguin Books.

Hamers, J. \& Blanc, M. (2000). Bilinguality and Bilingualism. Cambridge: Cambridge University Press. 
Liberali, C. F.; Magalhães, M. C. C; Meaney, M. C; Santiago, C.; Canuto, M \& Santos, J. A. A. dos. (2015). Projeto Digit-m-ed Brasil: uma proposta de desencapsulação da aprendizagem escolar por meio dos multiletramentos. Revista Prolíngua, 10(3), pp. 2-17.

Marcelino, M. (2009). Bilinguismo no Brasil: significado e expectativas. Revista Intercâmbio, xIx, pp. 1-22. Disponível em <http://www. pucsp.br/pos/lael/intercambio/pdf/1_Marcello_Bilinguismo\%20 no\%20Brasil.pdf>. Acesso em: 16 ago. 2012.

Martin-Jones, M.; Blackledge, A. \& Creese, A. (2012). Introduction: a sociolinguistics of multilingualism for our times. In M. Martin-Jones; A. Blackledge \& A. Creese (Orgs.). The Routledge Handbook of Multilingualism. (pp. 1-26). London: Routledge.

Mello, H. (2010). Educação bilíngue: uma breve discussão. Horizontes de Linguística Aplicada, 9(1), pp. 118-140.

Otsuji, E. \& Penycook, A. (2010). Metrolingualism: fixity, fluidity and language in flux. International Journal of Multilingualism, 7, (3), pp. 240-254. Disponível em <https://www.researchgate.net/publication/249025313_Metrolingualism_Fixity_Fluidit y_and_Language_ in_Flux>. Acesso em: 24 mar. 2017.

Rymes, B. (2014). Communicative Repertoire. In: B. Stree \& C. Leung. (Orgs.). Routledge Companion to English Language Studies. New York/London: Routledge.

Uphoff, D. (2007). As línguas do outro: reflexões sobre um caso de bilinguismo. Fragmentos, 33, pp. 229-243. Disponível em https://periodicos.ufsc.br/index.php/fragmentos/article/viewFile/8666/8007. Acesso em: 14 abr. 2017.

Vertovec, S. (2007). Super-diversity and its implications. Ethnic and racial studies, 30 (6), pp. 1024-1054.

Wortham, S. (2001). Narratives in action. New York: Teacher's College Press. 
